\title{
МЕДИЦИНСКАЯ ХИМИЯ - ВАЖНЕЙШЕЕ НАПРАВЛЕНИЕ ОРГАНИЧЕСКОГО СИНТЕЗА
}

\author{
B.Н. Чарушин \\ Институт органического синтеза им. И.Я. ПостовскогоУрО РАН, \\ 620108, Россия, г. Екатеринбург, ул. Софьи Ковалевской, 22.
}

DOI: 10.19163/MedChemRussia2021-2021-9Ｅ-mail:Valery-Charushin-562@yandex.ru

Один из приоритетов научно-технологического развития РФ связан с созданием и рациональным применением лекарственных препаратов, прежде всего антибактериальных. Пандемия коронавирусной инфекции показала, насколько важныпротивовирусные препараты. Глобальную угрозу представляет также нарастающая резистентность к антибиотикам.

Медицинская химия имеет своей целью создание лекарственных препаратов на основе данных о взаимосвязи структурыи активности веществ, а такжепредставлений о биологических мишенях их действия. Медицинская химия является наукой интегральной, использующей данные математического моделирования, физической и квантовой химии, компьютерной химии, биохимии, молекулярной биологии, фармакологии и медицины.

Эра химиотерапии начинается от Пауля Эрлиха, лауреата Нобелевской премии 1908 г. и Фридриха Баера, основавшего в 1899 г. первое в мире фармацевтическое производство аспирина. Современное здравоохранение невозможно представить без синтетических лекарственных препаратов. Объем мирового фармацевтического рынка превышает триллион долларов, причем США и Китай занимают более половины этого рынка, а доля России является довольно скромной (менее 3\%). Восстановившись после полного разгрома в 90-годы,фармпромышленность РФ уверенно демонстрирует в последнее десятилетие хорошие ежегодные темпы прироста. Принятая в 2009 г. программа «Фарма 2020» стала одной из самых успешных отраслевых программ. Улучшается структура российского фармрынка, однако доля оригинальных инновационных препаратов остается низкой и их создание остаетсяодной из актуальных задач медицинской химии.

Создание инновационных лекарств является очень затратным, трудоемким и рискованным (из 10000 кандидатов до аптеки доходит один препарат), но именно они определяют успех развития отрасли. Уральской научной школе химиков-органиков удалось создать целую линейку инновационных лекарственных препаратов, включая противовирусный риамиловир(триазавирин). Работы по триазавиринуи другим инновационным препаратам ведутся в рамках консорциума «Медицинская химия в создании лекарств нового поколения для лечения социально-значимых заболеваний», который объединил научные коллективы 8 научных учреждений (ИОС УрО РАН, УрФУ, ИОХ РАН, ИПХФ РАН, ИФАВ РАН, ИФОХ КНЦ РАН, НИОХ СО РАН, ВГМУ. УчастникИ консорциума решают сложные задачи создания противовирусных, антибактериальных, противоопухолевых препаратов, а также средств борьбы с нейродегенеративными заболеваниями.

Медицинская химия становится все более сложной наукой, использующей современный арсенал методов синтеза органических субстанций, растет доля энантиомерно чистых лекарств, совершенствуются представления о биомишенях и механизмах действия препаратов, а также аналитическая база исследований.

Развитие медицинской химии является важнейшим направлением фундаментальных исследований, определяющим перспективы развития отечественной фармпромышленности и готовность российского здравоохранения отвечать на глобальные вызовы. 